\title{
MALIGNANT HYPERPYREXIA AND DUCHENNE MUSCULAR DYSTROPHY: A CASE REPORT
}

\author{
Shigehiro OKa, Yoshio Igarashi, Akio Takagi, Mitsuhiro Nishida, Kazuo Sato, \\ KazUmasa Nakada AND KazUYuKI IKEDA
}

\begin{abstract}
We report a patient with Duchenne muscular dystrophy who developed malignant hyperpyrexia during general anaesthesia. During anaesthesia bradycardia was followed by ventricular fibrillation, on which ventricular flutter supervened and a body temperature rise of $0.6^{\circ} \mathrm{C}$ for 15 minutes, myoglobinuria and elevation of CPK level were observed. The caffeine sensitivity test of biopsied muscle fibers revealed an increase in sensitivity, although there was no sign of muscle rigidity during or after anaesthesia. Diagnosis of Duchenne muscular dystrophy was first established after the development of malignant hyperpyrexia in the present case as well as in previously reported cases. Determination of serum CPK is very important before general anaesthesia.
\end{abstract}

KEY WORDS: COMPLICATIONS, malignant hyperpyrexia, Duchenne muscular dystrophy.

MALIGNANT HYPERPYREXIA is a rare but a serious complication of general anaesthesia. Patients with neuromuscular problems are often susceptible to this syndrome, ${ }^{1,2}$ According to previous reports, patients with Duchenne muscular dystrophy (DMD) also developed this syndrome, presenting tachycardia, arrhythmia, cardiac arrest, myoglobinuria, rhabdomyolysis and marked elevation of creatine phosphokinase (CPK). ${ }^{3,4}$

We report a patient with DMD who developed malignant hyperpyrexia during general anaesthesia and results of the in vitro sensitivity test to caffeine are described.

\section{CASE Report}

The boy was bom after an uncomplicated full term pregnancy and delivery. His development seemed normal before admission. At age 21 months, he was hospitalized for operation for

Shigehiro Oka, M.D., Yoshio Igarashi, M.D., Mitsuhiro Nishida, M.D., Department of Paediatrics; Kazuo Sato, M.D., Kazumasa Nakada, M.D., Kazuyuki Ikeda, M.D., Department of Anaesthesiology, Hamamatsu University School of Medicine, Hamamatsu, Shizuoka 431-31, Japan; Akio Takagi, M.D., Division of Neuromuscular Research, National Center for Nervous, Mental and Muscular Disorders, Kodaira, Tokyo 187, Japan.

Address for Correspondence: Shigehiro Oka, M.D., Department of Paediatrics, Hamamatsu University School of Medicine, 3600 Handa-Cho, Hamamatsu-Shi, Shizuoka-Ken 431-31, Japan. ankyloglossia. An electrocardiogram before anaesthesia was normal. On laboratory examinations, the serum levels of sodium, potassium and chloride were within normal limits, but CPK, LDH, GOT and GPT were not examined. After premedication with atropine sulphate $0.2 \mathrm{mg}$ intramuscularly and hydroxyzine pamoate $10 \mathrm{mg}$ per os, anaesthesia was induced by inhalation of a gas mixture of halothane, nitrous oxide and oxygen. After intravenous succinylcholine 10 $\mathrm{mg}$ the heart rate dropped, and ventricular fibrillation and supervening ventricular flutter occurred. The skeletal muscle, however, was not rigid at any time. Anaesthesia was suspended and closed cardiac massage was begun. Ten minutes later the heart beat returned to normal and 30 minutes later the patient regained consciousness. The colour of the urine became dark red. The body temperature rose to $38^{\circ} \mathrm{C}$ after the beginning of anaesthesia, which amounts to an elevation rate of $0.6^{\circ} \mathrm{C}$ for 15 minutes. Two hours later, body temperature fell to $37.2^{\circ} \mathrm{C}$. The serum levels of sodium, potassium and chloride were $135,5.3$ and $100 \mathrm{mmol} / \mathrm{l}$, respectively. Serum CPK was $183678 \mathrm{IU}$ (normal $25-115 \mathrm{IU}$ ) and serum myoglobin was 12400 $\mathrm{ng} / \mathrm{ml}$. These data indicated that the red colour of the urine was due to myoglobinuria. The arterial blood gas analysis during breathing of 100 per cent oxygen showed $\mathrm{pH} 7.4, \mathrm{PO}_{2} 66 \mathrm{kPa}(496.4$ $\mathrm{mmHg}), \mathrm{PCO}_{2} 3.8 \mathrm{kPa}(28.6 \mathrm{mmHg})$ and base excess $-5.0 \mathrm{mmol} / \mathrm{l}$.

Can. Anaesth. Soc. J., vol. 29, no. 6, November 1982 
Throughout the following two months, serum CPK level remained constantly between 10164 and $17182 \mathrm{IU}$. On physical examination Gower's sign was observed. However, weakness of other muscles, muscle atrophy, pseudohypertrophy of gastrocnemius and clumsy waddling gait were not observed. Sitting and walking postures were normal. At age two years, he was admitted again for clinical evaluation. $\mathrm{CBC}$, $\mathrm{Na}, \mathrm{K}, \mathrm{Cl}$, inorganic phosphorus, total calcium, BUN, total cholesterol and total protein were found within the normal limits by laboratory examination. The serum creatinine level was $0.4 \mathrm{mg} / \mathrm{dl}$. The 24 -hour endogenous creatinine clearance test produced $521 /$ day, which was considered low, but the Fishberg test showed a normal renal concentrating ability. Elevation of the serum levels of LDH (5664. Wroblewski), GOT (311 KU), GPT (369 KU), CPK (10043 IU), myoglobin $(420 \mathrm{ng} / \mathrm{dl})$ and creatine $(1.06$ $\mathrm{mg} / \mathrm{dl}$ ) were observed, but the serum levels of alkaline phosphatase $(12.9 \mathrm{KAU})$ and $\gamma$-GTP (10 IU) were normal. Urinary excretion of myoglobin and creatine were also elevated, i.e., $34 \mathrm{ng} / \mathrm{ml}$ and $0.14 \mathrm{~g} /$ day respectively. CPKisozyme of muscle origin was dominant. The electromyogram of left quadriceps femoris showed normal findings. After intramuscular premedication with diazepam $5 \mathrm{mg}$, hydroxyzine hydrochloride $15 \mathrm{mg}$, and pethidine hydrochloride $1.5 \mathrm{mg}$, biopsy of left quadriceps fermoris muscle was done under intravenous anaesthesia (diazepam $5 \mathrm{mg}$ and pethidine hydrochloride $3.5 \mathrm{mg}$ ) and local anaesthesia with mepivacaine hydrochloride. Histological examination of the biopsied muscle showed variations in fiber diameter, necrotic foci and endomysial fibrosis. These findings were compatible with diagnosis of DMD. An in vitro sensitivity test to caffeine was done using a chemical skinned fiber preparation. A small bundle comprising 5 to 6 muscle fibers was incubated for two minutes in a solution containing $3 \times 10^{-7} \mathrm{M}$ free calcium ion. During the incubation the sarcoplasmic reticulum accumulated calcium. After calcium loading, the threshold concentration of caffeine that caused muscular contracture was determined. ${ }^{5}$ The muscular contracture was induced by a lower concentration of caffeine in the present case than in other cases of DMD, Ullrich disease or cases with hypotonia, indicating the enhancement of caffeine sensitivity. (Figures 1 \& 2, Table I.)

Serum CPK was measured among members of his family. Serum CPK activity was normal in

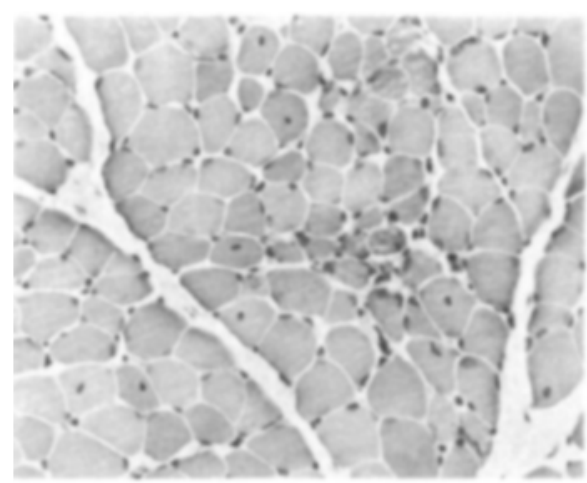

FIGURE 1 Microscopic appearance of quadriceps femoris muscle, haematoxylin-eosin preparation.

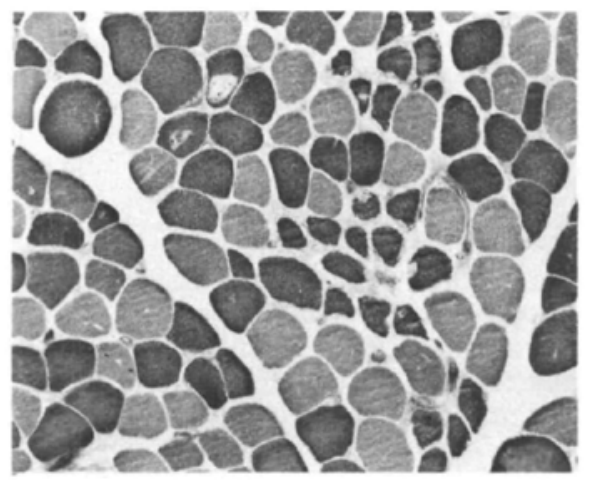

FIGURE 2 Microscopic appearance of quadriceps femoris muscle, routine ATPase preparation.

his father and elder brother, while moderately elevated in his mother (CPK: $484 \mathrm{IU}$ ).

\section{Discussion}

Complications during anaesthesia in patients with DMD have been reported by Miller, et al. ${ }^{3}$ and Seay, et $a l .^{4}$ Diagnosis of DMD was not established before anaesthesia in those patients. These complications were tachycardia, cardiac arrest, myoglobinuria, acidosis, hypercarbia and marked elevation of CPK level. Some patients presented muscular rigidity ${ }^{4}$ but others did not ${ }^{3}$. The in vitro halothane sensitivity test of muscle fibers was negative in the case reported by Miller, et al. ${ }^{3}$, and there was no elinical sign of muscle rigidity in Miller's case.

In the present case, bradycardia was followed by ventricular fibrillation, on which ventricular flutter supervened. The body temperature rise of 
TABLE I

THREsholdD CONCENTRATION OF CAFFEINE FOR Muscle Contracture IN Vitro

\begin{tabular}{cccc}
\hline $\begin{array}{c}\text { Threshold } \\
\text { concentration } \\
(\mathrm{mM})\end{array}$ & $\begin{array}{c}\text { Present } \\
\text { case }\end{array}$ & $\begin{array}{c}\text { Other } \\
\text { DMD } \\
\text { cases* }\end{array}$ & $\begin{array}{c}\text { Other } \\
\text { diseases } \dagger\end{array}$ \\
\hline 2.5 & $2 \ddagger$ & 0 & 1 \\
5.0 & 3 & 6 & 5 \\
7.5 & 0 & 2 & 5 \\
10.0 & 0 & 3 & 1 \\
$>12.5$ & 0 & 4 & 3 \\
\hline
\end{tabular}

*Includes four patients of age 5, 5, 6 and 6 .

†Four patients with Ullrich disease (age 2 months) and hypotonia of undetermined origin (19 months, 20 months and 30 months).

\$Indicates the number of muscle bundles contracted with caffeine threshold concentration shown indicated in the left column.

$0.6^{\circ} \mathrm{C}$ for 15 minutes, hyperkalaemia, myoglobinuria and elevation of CPK level were observed, and rigidity of muscle did not appear. The presence of acidosis was not confirmed in the blood gas analysis, probably due to 100 per cent oxygen supply to the patient. The caffeine sensitivity test of biopsied muscle fibers revealed an increase in sensitivity, although there was no sign of muscle rigidity during or after anesthesia.

Of the three patients with malignant hyperpyrexia reported by Kalow, Britt, et al. ${ }^{6}$ one was without rigidity. The sensitivity to caffeine of the muscle from a non-rigid patient was almost equal to that of the muscle from normal controls. ${ }^{6}$ This then suggests that malignant hyperpyrexia with and without rigidity are different entities, having different aetiology. ${ }^{6}$ Strobel and Bianchi ${ }^{7}$ proposed a tentative aetiological classification of malignant hyperpyrexia: the case with rigidity is associated with an abnormality in calcium uptake by the sarcoplasmic reticulum and in the case without rigidity, the function of mitochondria may be disturbed by anaesthetic agents. Although definitive rigidity was not observed in the present case the muscle showed an increased sensitivity to caffeine, contrary to
Kalow's observation. In the present study, the sarcoplasmic reticulum of muscle fiber was loaded with calcium ion each time before challenge with caffeine. This might explain the difference. However, these aspects need further study.

Diagnosis of DMD was first established after the development of malignant hyperpyrexia in the present case as well as in previously reported cases. This report indicates that determination of serum CPK is very important before general anaesthesia. Further work seems necessary to evaluate the clinical significance of the in vitro sensitivity test using biopsy specimens.

\section{ACKNOWLEDGEMENTS}

The authors with to thank Dr. Nonaka for the histochemical examination of biopsy muscle.

\section{REFERENCES}

1. Denborough, M.A., Dennett, X. \& AnderSON, R.MC.D. Centralcore disease and malignant hyperpyrexia. British Med. J. 1: 272 (1973).

2. King, J.O., Den borough, M.A. \& ZAPF, P.W. Inheritance of malignant hyperpyrexia. Lancet $i$ : 365 (1972).

3. Miller, E.D. Sanders, D.B. Rowlingson, J.C., BERRY, F.A., Sussman, M.D. \& EPSTEIN, R.M. Anesthesia-induced rhabdomyolysis in a patient with Duchenne's muscular dystrophy. Anesthesiology 48: 146 (1978)

4. Seay, A.R., Ziter, F.A. \& Thompson, J.A. Cardiac arrest during induction of anesthesia in Duchenne muscular dystrophy. J. Pediat. 93: 88 (1978).

5. Takagi, A., Yonemoto, K. \& Sugita, H. Single-skinned human muscle fibers: Activation by calcium and strontium. Neurology 28: 497 (1978).

6. Kalow, W., Britt, B.A., Terreau, M.E. \& HaIST, C. Metabolic error of muscle metabolism after recovery from malignant hyperpyrexia. Lancet ii: 895 (1970).

7. Strobel, G.E. \& Bianchi, C.P. An in-vitro model of anesthetic hypertonic hyperpyrexia, halothane-caffeine-induced muscle contractures. Anesthesiology 35: 465 (1971).

\section{RESUME}

Les auteurs rapportent le cas d'un malade souffrant de dystrophie musculaire progressive type Duchenne qui développa une hypcrpyrexie maligne pendant l'anesthésie générale. Une bradycardie évolua en fibrillation ventriculaire qui se transforma par la suite en flutter ventriculaire pendant que la température corporelle s'élevait de $0.6^{\circ} \mathrm{C}$ pendant 15 minutes. Une myoglobinurie et une élévation des taux de C.P.K. ontété observées. La sensibilité à la cafếne sur les fibres musculaires prélevées était augmentée bien qu'on n'ait pas observé de rigidité pendant et après l'anesthésie. Le diagnostic de dystrophie musculaire progressive type Duchenne a été porté dans le cas présent après la crise d'hyperpyrexie maligne. Le dosage des C.P.K. est une analyse importante avant une intervention. 